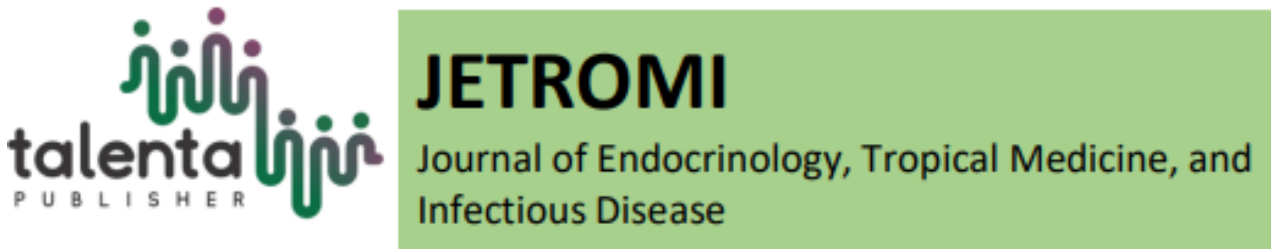

\title{
A 46-year-Oldman with Gynaecomastia and Cirrhosis Hepatis Child Plug A. A case Report
}

\author{
Syarifah Dian*1, Melati Silvani ${ }^{2}$ \\ ${ }^{1}$ Department of Internal Medicine, Faculty of Medicine, University Sumatera Utara, Medan, North \\ Sumatera, Indonesia \\ ${ }^{2}$ Division of Endocrinologist, Department of Internal Medicine, Faculty of Medicine, University \\ Sumatera Utara, Medan, North Sumatera, Indonesia
}

\begin{abstract}
Background: Gynecomastia is defined as the presence of excessive breast tissue in males, which can appear unilateral or bilateral. Bilateral prepubertal gynecomastia in the absence of endocrine abnormalities is extremely rare, with only a few cases in literature.

Case Presentation: A 46-year-old man presented with a 2 years history of bilateral breast enlargement and pain. There is heartburn, shrinking testicles, and decreased sexual drive. Vital examination showed normal. BMI $: 24.0 \mathrm{~kg} / \mathrm{m}^{2}$. Head dan neck: normal. On the chest both breasts are enlarged as avocados, palpable time around areola, chewy contingency, press pain, galactorrhea negative. Lung and cast are normal. In the abdominal: hepar, lien and renal are not palpable, and ascites are not found. There is an atrophy of testicles. Previous history of hepatic cirrhosis with Esophageal Varicose Veins caused by Hepatitis B. Laboratory examination Estradiol $98.71 \mathrm{pg} / \mathrm{mL}$ (range: <62), Testosterone: $8.66 \mathrm{ng} / \mathrm{mL}$ (range: 3.0-10.6), LH5.53 mlU/mL, FSH $6.49 \mathrm{mlU} / \mathrm{mL}$, Prolactin $5.08 \mathrm{ng} / \mathrm{mL}$; Total T4 5.57 ng/dL, TSH $1.84 \mu \mathrm{IU} / \mathrm{mL}$. SGOT U/L 53, SGPT 71 U/L, Hepatitis B (+), HBsAg Reactive S/CO 414.46; HBeAg: Non Reactive, HBV DNA Undetectable and Albumin 3.6 g/dL. Fibroscan: Cirrhosis Hepatis. Abdominal ultrasound: Cirrhosis Hepatis. Gastroscopy: Esophageal Varicose Veins (F1, LI, CB) + Pan Gastropathy.

Conclusion: Reportedly A 46-year-old man presented with gynaecomastia bilateral with Cirrhosis Hepatis Child Plug A, given conservative treatment with tamoxiphen for 1 month
\end{abstract}

Keywood: Gynaecomastia, Cirrhosis Hepatis \footnotetext{
Medan, North Sumatera, Indonesia

E-mail address: syarifah.dianrosa09@gmail.com

*Corresponding author at: Department of Internal Medicine, Faculty of Medicine, University Sumatera Utara, 
ABSTRAK

Latar Belakang: Ginekomastia didefinisikan sebagai terdapat jaringan payudara yang berlebihan pada laki-laki, yang dapat muncul unilateral atau bilateral. Ginekomastia prepubertal bilateral tanpa adanya kelainan endokrin sangat jarang terjadi, terdapat hanya beberapa kasus dalam literatur.

Presentasi Kasus: Seorang pria berusia 46 tahun mengalami pembesaran payudara bilateral selama 2 tahun dan juga merasa sakit. Ada mulas, testis menyusut, dan penurunan gairah seksual. Pemeriksaan vital menunjukkan normal. Didada kedua payudara membesar seperti buah alpukat, sekitar areola menghitam, konsistensi kenyal, nyeri, galactorrhea (-). Paru dan jantung. normal. Pada abdominal: hepar, lien dan ginjal tidak teraba, dan ascites (-). Ada atrofi testis. Sebelumnya riwayat sirosis hati dengan varises Esopagus yang disebabkan oleh Hepatitis B. IMT: 24,0 kg/m². Pemeriksaan laboratorium Estradiol 98,71 pg/mL (rentang: <62), testosteron: 8,66 ng/mL (rentang: 3,0-10,6), LH 5,53 mlU/mL, FSH 6,49 mlU/mL, Prolactin 5,08 ng/mL; Total T4 5,57 ng/dL, TSH 1,84 $\mu \mathrm{IU} / \mathrm{mL}$. SGOT $53 \mathrm{U} / \mathrm{L}$, SGPT 71 U/L, Hepatitis B (+), HBsAg Reaktif S/CO 414,46; HBeAg: Non Reaktif, DNA HBV tidak terdeteksi dan albumin 3,6 g/dL. Fibroscan: Cirrhosis Hepatis. USG Abdominal: Cirrhosis Hepatis. Gastroskopi: Esophageal Varises (F1, LI, CB) + Pan Gastropati.

Kesimpulan: Dilaporkan Seorang pria berusia 46 tahun dengan ginaekomastia bilateral dan Cirrhosis Hepatis Child Plug A, diberikan pengobatan konservatif dengan tamoxiphen.

Kata Kunci: Ginekomastia, Hirosis Hepatis, tamoxiphen

Received 12 May 2021 | Revised 27 May 2021 | Accepted 31 May 2021

\section{Introduction}

Gynecomastia is defined as the benign enlargement of the male breast, usually, a result of stromal proliferation and ductal hyperplasia. which can appear unilateral or bilateral. Bilateral gynecomastia is frequently found in the neonatal period, early in puberty, and with increasing age. Prepubertal bilateral gynecomastia in the absence of endocrine abnormalities is extremely rare, with only a few cases in literature.[1]

Among the underlying causes, 3 groups of triggers are distinguished: physiologic, pathologic and pharmacologic/toxic. Pathophysiologically, female hormone imbalance has been shown to trigger glandular growth. This imbalance may in turn also be of pathologic or physiologic/idiopathic origin. There is strong evidence for the stimulating effect of estrogen on breast tissue development. Any disorder or medication leading to female hormone imbalance can trigger gynecomastia. Endogenous diseases like hyperthyroidism, chronic liver disease, primary or secondary gonadal failure, androgen resistance syndromes, medication, and lifestyle factors like drug abuse represent typical causes of gynecomastia [2]. Classification of gynecomastia [3]. Terdiri dari Grade I: minimal hypertrophy $<250$ g breast tissue; Grade II: moderate hypertrophy 250-500 g breast tissue without ptosis; Grade III; severe hypertrophy $>500 \mathrm{~g}$ breast tissue with grade I ptosis and Grade IV. severe hypertrophy with grade II-III ptosis. 
In most cases, gynecomastia is caused by short- term hormonal fluctuations that limit themselves physiologically, which can occur neonatally, during puberty, and in elderly men. In the neonatal period, a preliminary physiologic bilateral mammary glandular swelling is triggered by maternal placental estrogens and resolves within a few weeks after birth. In adolescence, physiologic pubertal gynecomastia can develop and may last up to 6 months. This is triggered by a relative estrogen excess, mainly due to peripheral aromatization of the testicular and adrenal androgens. Testicular testosterone production increases in late puberty and leads to a spontaneous regression of the gynecomastia [4]. Due to a decrease in testosterone production and an increase in sex hormone-binding globulin, gynecomastia is also common in elderly men.

\section{Case report:}

An 46-year-old-man presented with a 2 years history of bilateral breast enlargement and pain. There is heartburn, shrinking testicles, decreased sexual drive, and no confidence. No history or sign of galactorrhea existed. Physical examination showed normal. BMI: $24.0 \mathrm{~kg} / \mathrm{m}^{2}$. Head dan Neck: normal. On the chest, both breasts are enlarged as avocados, palpable time around areola, chewy contingency, press pain, galactorrhea negative. Lung and cor is normal. In the abdominal: hepar, lien and renal is not palpable, and ascites are not found. gender: Male and there is atrophy of testicles. Previous history of hepatic cirrhosis with Esophageal Varicose Veins caused by Hepatitis B.

\section{Laboratory Results}

Urine, blood sugar and cholesterol are normal. Estradiol $98.71 \mathrm{pg} / \mathrm{mL}$ (high), Testosterone: 8.66 ng/mL (high), LH 5.53 mlU/mL, FSH 6.49 mlU/mL, Prolactin 5.08 ng/mL; Total T4 5.57 ng/dL , TSH $1.84 \mu \mathrm{IU} / \mathrm{mL}$. SGOT $53 \mathrm{U} / \mathrm{L}$, SGPT $71 \mathrm{U} / \mathrm{L}$, Hepatitis B (+), HBsAg Reactive S/CO 414.46; HBeAg: Non Reactive, HBV DNA Undetectable and Albumin 3.6 g/dL.

Mammae Ultrasound: Both mamae enlarge asymmetrically, left is larger than the right. Both mammae consist of fatty and fibroglandural components, but are more dominant fibroglandular in both mamaes especially the leftones (fig 1). There is no visible enlargement of the lymph nodes on both axillas. Impressions: Gynecomastia on the right and left mammae. Fibroscan: Sirosis Hepatis. Abdominal ultrasound: Hepar, irreguler surface, blunt edge, shrinking size, coarse homogeneous parenym. Conclusion: Cirrhosis Hepatis. Gastroscopy: Esophageal Varicose Veins $(\mathrm{F} 1, \mathrm{LI}, \mathrm{CB})+$ Pan Gastropathy.

Diagnosis: gynaecomastia in the right and left mammae and Cirrhosis Hepatis Child Plug A, Hepatitis B, Varicose Veins of the Oesophagus. Diagnosis is bilateral gynaecomastia with Cirrhosis Hepatis Child Plug A, given conservative treatment with tamoxiphen for 1 month 


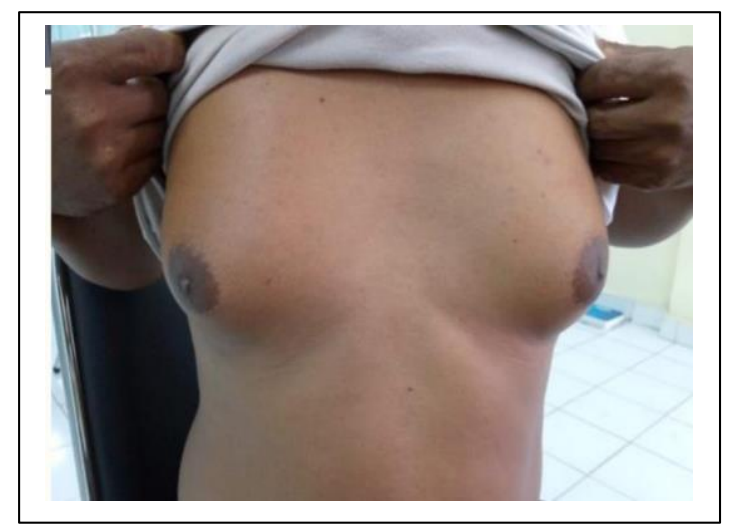

Figure 1

\section{Discussion}

Gynecomastia correlated directly with body mass index (BMI) and with age. Individuals with more severe cirrhosis usually are very thin, although the BMI may be increased owing to the pres $\neg$ ence of ascites or peripheral edema. It has been suggested that gynecomastia in all subjects is the result of a reduced circulating testosterone concentration, an elevated estrogen concentration, or both resulting in an increase in the estrogen-testosterone ratio.[5] Men with cirrhosis have decreased production of testosterone, increased production of androstenedione, increased conversion of androstenedione to estrone, and increased levels of sex hormone-binding globulin.[6] same in the control subjects and those with cirrhosis, even though the estrogentestosterone ratios were much lower in the controls.

In the case of true gynecomastia, clinical examination by palpation followed by ultrasound examination and if necessary mammography reveal glandular tissue. Palpation of the breast should be able to clinically distinguish fatty tissue from glandular tissue and should include a more detailed assessment of the breast such as ptosis, skin excess, and nipple retraction. The physical examination should also extend to testicular palpation in order to detect testicular changes and atrophies at an early stage and to pave the way for further diagnostic measures. In particular, in young men with a negative history and bilateral gynecomastia, the incidence of testicular endocrine tumors is showing a significant increase [7]. The diagnosis of gynecomastia must be confirmed histologically by a sonographically, showing a $90 \%$ sensitivity and specificity [8]. Standard diagnostics include laboratory tests like human choric gonadotropin, luteinizing hormone, thyroid-stimulating hormone, testosterone, and estradiol [9].

\section{Conservative and Surgical Management}

he therapy of gynecomastia may be conservative or surgical. Conservative therapy must be based on the cause of the gynecomastia. Self-limiting physiologic forms of gynecomastia should be followed up until resolved. In the case of persistence or progress, if necessary, laboratory diagnostic tests should be repeated to detect hormonal processes as quickly as possible. A 
conservative therapy option is the administration of serum estrogen receptor modulators such as tamoxifen. Tamoxifen at a daily oral dose of $20 \mathrm{mg}$ for up to 3 months has shown good results in randomized and non-randomized trials. and post-traumatic deep vein thrombosis, are rarely reported [9]. The use of anastrozole, an aromatase inhibitor, is not recommended as it did not show more effectiveness than placebo in boys with pubertal gynecomastia [11]. If conservative pharmacologic therapy attempts are to be considered, it should be noted that hypertrophic glandular tissue becomes irreversibly fibrotic by way of remodeling after no more than 12 months. This fibrous tissue cannot be removed conservatively and proceeding with surgical management must be considered.[12] The indication for surgical therapy is based on the patient's suffering, including psychosocial stress and pain as well as cosmetic distortion [13]. The aim of all surgical procedures is to remove the hypertrophic fibrotic glandular tissue and to reestablish the male breast shape. Therapeutic techniques include breast tissue resection, liposuction, and combined techniques. From stage III onwards, reduction mammoplasty should be explored taking into Regression of gynecomastia is seen in up to $80 \%$ of patients [14]. However, the available data on tamoxifen stems from few studies with very small case numbers [15]. Adverse side effects, including epigastric distress consideration the extent of the hypertrophic tissue and the expertise of the surgeon [16]. For milder forms, the periareolar edge cut to the mastectomy can suffice.

\section{Conclusion.}

Reportedly A 46-year-old man presented with gynaecomastia bilateral with Cirrhosis Hepatis Child Plug A, given conservative treatment with tamoxiphen for 1 month

\section{REFERENCES}

[1] Antonio Cutrupi, , M. Barbalace, C. Covani , S. Malavenda. Bilateral Gynecomastia: A report of one case. Int $\mathrm{J}$ Ped \& Neo Heal. vol.1, no,1, pp.04-06. 2016. DOI:10.25141/2572-4355-2017-1.0004

[2] Johnson RE, Murad MH: Gynecomastia: phathophysiology, evaluation, and management. Mayo Clin Proc vol.84:pp,1010-5. 2009

[3] Rohrich RJ, Ha RY, Kenkel JM, Adams WP Jr: Classification and management of gynecomastia: defining the role of ultrasound-assisted liposuction. Plast Reconstr Surg; vol,111:pp.909-23. 2003

[4] Nordt C, Divanta A: Gynecomastia in adolescents. Curr Opin Pediatr vol.20:pp.375-82. 2008

[5] Frantz AG, Wilson JD. Endocrine disorders of the breast. In: Wilson JD, Foster DW, eds. Williams Textbook ofEndocrinology. Philadelphia, Pa: WB Saunders Co pp.410-16. 1985

[6] Kley, HK, Niederau C, Stremmel W, Lax R, Strohmeyer G, Kruskemper HL. Conversion of androgens to estrogens in idiopathic hemochromatosis: comparison with alcoholic liver cirrhosis. J Clin Endocrinol Metab vol.61:pp.1-6. 1985

[7] Bowers SP, Pearlman NW, McIntyre RC Jr, Finlayson CA, Huerd S: Cost-effective management of gyneco- mastia. Am J Surg, vol.176, pp,638-41. 1998

[8] Morcos RN, Kizy T: Gynecomastia. When is treatment indicated? J Fam Pract vol.61, pp.719-25. 2012

[9] Evans GF, Anthony T, Turnage RH, et al: The diagnos- tic accuracy of mammography in the evaluation of male breast disease. Am J Surg vol.181:pp. 96-100. 2001 
[10] Ting ACW, Chow LWC, Leung YF: Comparison of ta- moxifen with danazol in the management of idiopathic gynecomastia. Am Surg vol.66:pp.38-40. 2000

[11] Plourde PV, Reiter EO, Jou HC, et al: Safety and efficacy of anastrozole for the treatment of pubertal gynecomastia: a randomized,double-blind, placebo-controlled trial. J Clin Endocrinol Metab vol.89: pp.4428-33. 2004

[12] Bannayan GA, Hajdu SI: Gynecomastia: clinicopathologic study of 351 cases. Am J Clin Pathol vol.57:pp. 431-7. 1972

[13] Ordaz DL, Thompson JK: Gynecomastia and psychological functioning: a review of the literature. Body Image vol.15:pp.141-148. 2015

[14] Hanavadi S, Banerjee D, Monypenny IJ, Mansel RE: The role of tamoxifen in the management of gynaecomastia. Breast vol.15, no.79:pp.276-80. 2006

[15] Johnson RE, Kermott CA, Murad MH: Gynecomastia - evaluation and current treatment options. Ther Clin Risk Manag vol.7:pp.145-8. 2011

[16] Wolter A, Scholz T, Diedrichson J, Liebau J: Surgical treatment of gynecomastia: an algorithm (Article in German). Handchir Mikrochir Plast Chir vol.45:pp.7379. 2013 